\title{
Penerapan Pendekatan Pendidikan Matematika Realistik Indonesia (PMRI) ditinjau dari Multiple Intelligences
}

\author{
Frika Septiana $^{1 *}$, Mujib ${ }^{1}$, Hasan Sastra Negara ${ }^{1}$ \\ ${ }^{1}$ Jurusan Pendidikan Matematika, Universitas Islam Negeri Raden Intan Lampung. \\ Jalan Endro Suratmin, Sukarame, Bandar Lampung 35133, Indonesia. \\ *Corresponding Author . E-mail: frikaseptiana12@gmail.com
}

Received : 17-11-2017; Revised: 06-01-2018; Accepted : 29-01-2018

\begin{abstract}
Abstrak
Tujuan dalam penelitian ini yaitu untuk mengetahui apakah terdapat: (1) pengaruh pendekatan PMRI terhadap kemampuan pemecahan masalah matematis peserta didik; (2) pengaruh antara kategori kemampuan multiple intelligences terhadap kemampuan pemecahan masalah matematis; (3) terdapat interaksi antara pendekatan PMRI dengan multiple intelligences terhadap kemampuan pemecahan masalah matematis. Penelitian ini merupakan penelitian quasy eksperimental design dengan desain faktorial $2 \times 3$. Teknik pengambilan sampel dalam penelitian ini menggunakan probability sampling dengan cluster random sampling. Instrumen penelitian yang digunakan adalah tes kemampuan pemecahan masalah matematis dan angket multiple intelligences. Data hasil tes kemampuan pemecahan masalah matematis dianalisis menggunakan uji anava dua jalan sel tak sama. Hasil penelitian menunjukkan bahwa: (1) terdapat pengaruh pendekatan PMRI terhadap kemampuan pemecahan masalah matematis peserta didik; (2) terdapat pengaruh antara kategori kemampuan multiple intelligences terhadap kemampuan pemecahan masalah matematis; (3) tidak terdapat interaksi antara pendekatan PMRI dengan multiple intelligences terhadap kemampuan pemecahan masalah matematis.
\end{abstract}

Kata Kunci: Multiple Intelligences, PMRI, Pemecahan Masalah Matematis

\begin{abstract}
The purpose of this research is to know if there are: (1) the influence of PMRI approach to the problem-solving ability of mathematical learners; (2) the influence between multiple intelligences capability categories of mathematical problem solving abilities; (3) there is an interaction between PMRI approach with multiple intelligences on mathematical problem solving ability. This research is a quasi-experimental design research with $2 \times 3$ factorial design. Sampling technique in this research use probability sampling with cluster random sampling. The research instrument used is the test of mathematical problem-solving ability and multiple intelligences questionnaire. The resulting data of mathematical problem-solving test were analyzed by using another test of two different cell paths. The result of the research shows that: (1) there is an influence of PMRI approach to students' mathematical problem solving ability; (2) there is influence between categories of multiple intelligences ability in mathematical problem solving ability; (3) there is no interaction between PMRI approach with multiple intelligences on mathematical problem solving ability.
\end{abstract}

Keywords: Mathematical Problem Solving, Multiple Intelligences, RME.

PENDAHULUAN

Pelajaran matematika merupakan salah satu mata pelajaran yang memiliki manfaat besar dalam kehidupan. Matematika memberikan kesempatan kepada peserta didik untuk melatih mental mereka dan akan berpengaruh terhadap perkembangan intelektual mereka. Melalui pembelajaran matematika di sekolah, diharapkan peserta didik akan mampu belajar untuk memperoleh pengetahuan secara sistematis ataupun cara memecahkan suatu masalah matematis (Ayda \& Widjajanti, 2014). Kemampuan pemecahan masalah merupakan 
kemampuan yang sebaiknya dimiliki oleh setiap peserta didik, karena kemampuan ini dapat membantu kita dalam menyelesaikan masalah dalam kehidupan sehari-hari. Namun demikian, kemampuan pemecahan masalah peserta didik dalam pelajaran matematika masih rendah (Gusnidar, Netriwati, \& Putra, 2018). Padahal kemampuan pemecahan masalah dalam matematika adalah salah satu aspek penting dalam pembelajaran matematika (Putra, 2017). Mengatasi rendahnya kemampuan pemecahan masalah matematis tersebut penulis ingin menerapkan suatu pendekatan dimana peserta didik dilibatkan langsung dalam kehidupan nyata sehingga peserta didik memiliki pengalaman yang baik dalam proses memahami materinya.

Pembelajaran matematika yang mengaitkankan pengalaman peserta didik dalam kehidupan sehari-hari dengan konsep-konsep matematika adalah Pendidikan Matematika Realistik Indonesia (PMRI). Pendidikan Matematika Realistik Indonesia (PMRI) memiliki karakteristik membuat siswa lebih aktif berpikir, konteks dan bahan ajar terkait langsung dengan lingkungan sekolah dan siswa, dan peran guru lebih aktif dalam merancang bahan ajar dan kegiatan kelas (Sembiring, 2014). Berdasarkan beberapa penelitian yang telah ada pendekatan ini juga telah memberikan hasil yang positif bagi para peerta didik (Astuti, 2014; Idris \& Silalahi, 2016; Muchlis, 2012). Melalui kegiatan pembelajaran dengan pendekatan PMRI peserta didik diharapkan dapat mengembangkan kemampuan pemecahan masalah matematis. Untuk membedakan penelitian ini dengan penelitian yang sudah ada, maka akan ditambahkan lagi satu variabel yang diduga mempengaruhi kemampuan pemecahan masalah matematis peserta didik yaitu kemampuan multiple intelligent.
Multiple intelligences merupakan berbagai bentuk keterampilan yang dimiliki peserta didik untuk menyelesaikan berbagai persoalan dalam pembelajaran (Yaumi \& Ibrahim., 2016). Berdasarkan pada teori Multiple Intelligence bahwa setiap peserta didik memiliki aneka ragam kecerdasan yaitu meliputi; bahasa, logika, musikal, visual atau spasial, kinestetik, intrapersonal dan interpersonal, (Jasmine dalam (Huda \& Arief, 2013)). Kecerdasan tersebutlah yang akan membantu peserta didik dalam mengatasi permasalahan yang ada ketika peserta didik tersebut berada dalam suatu pembelajaran. Dalam penelitian ini, peneliti hanya mengambil tiga tipe kecerdasan yaitu kecerdasan logismatematik, kecerdasan verbal-linguistik, dan kecerdasan interpersonal.

Beberapa hasil penelitian terdahulu juga memberikan hasil bahwa kemampuan multiple intelligences mempengaruhi hasil belajar peserta didik (Huda \& Arief, 2013); (Widayanti, 2010). Oleh karena itu peneliti tertarik untuk mengadakan penelitian yang berjudul Penerapan Pendekatan PMRI Terhadap Kemampuan Pemecahan Masalah Matematis Ditinjau Dari Multiple Intelligences Peserta didik. Tujuan dalam penelitian ini yaitu untuk (1) Mengetahui apakah pendekatan PMRI menghasilkan kemampuan pemecahan masalah matematis lebih efektif dibandingkan dengan pendekatan konvensional; (2) Mengetahui apakah terdapat perbedaan pengaruh antara multiple intelligences terhadap kemampuan pemecahan masalah matematis; (3) Mengetahui apakah terdapat interaksi antara pendekatan PMRI dengan multiple intelligences terhadap kemampuan pemecahan masalah matematis.

\section{METODE}

Penelitian ini merupakan penelitian quasy eksperimental design dengan desain faktorial $2 \times 3$. Dalam penelitian ini 
peserta didik dibagi menjadi dua kelompok. Kelompok pertama adalah kelompok eksperimen, yaitu peserta didik yang mendapat perlakuan pembelajaran matematika dengan pendekatan PMRI. Kelompok kedua adalah kelompok kontrol, yaitu peserta didik yang mendapat perlakuan pembelajaran matematika dengan pendekatan konvensional. Teknik pengambilan sampel dalam penelitian ini menggunakan probability sampling dengan cluster random sampling. Probability sampling yaitu teknik pengambilan sampel yang memberikan peluang yang sama bagi setiap unsur (anggota) populasi untuk dipilih menjadi anggota sampel (Sugiyono, 2011).

Instrumen penelitian yang digunakan adalah tes kemampuan pemecahan masalah matematis dan angket multiple intelligences. Uji coba instrumen terdiri dari uji validasi isi dan validasi konstruk (validitas, reliabilitas, tingkat kesukaran, dan daya beda). Teknik analisis data yang digunakan dalam penelitian yaitu menggunakan uji anava dua jalan sel tak sama.

\section{HASIL DAN PEMBAHASAN}

Dari hasil uji prasyarat diperoleh bahwa kelas eksperimen dan kelas kontrol merupakan sampel yang berasal dari populasi yang berdistribusi normal dan homogen. Setelah uji prasyarat dilakukan uji analisis variansi dua jalan sel tak sama. Hasil analisis data pada uji analisis variansi dua jalan sel tak sama dapat dilihat pada Tabel 1 sebagai berikut:

Tabel 1. Analisis Variansi Dua Jalan Sel Tak Sama

\begin{tabular}{cccccc}
\hline Sumber & $\mathrm{JK}$ & $\mathrm{Dk}$ & $\mathrm{RK}$ & $\mathrm{F}_{\text {obs }}$ & $\mathrm{F} \alpha$ \\
PMRI(A) & 4049,501 & 1 & 4049,501 & 34,662 & 4049,501 \\
Multiple Intelligences (B) & 3515,621 & 2 & 1757,811 & 15,046 & 3,187 \\
Interaksi (AB) & 17,058 & 2 & 8,529 & 0,073 & 3,187 \\
Galat & 5724,623 & 49 & 116,829 & - & - \\
Total & 13306,803 & 54 & - & - & - \\
\hline
\end{tabular}

Berdasarkan analisis variansi dua jalan sel tak sama pada Tabel 1., dapat disimpulkan bahwa:

1) Berdasarkan perhitungan analisis variansi dua jalan sel tak sama bahwa $\mathrm{F}_{\text {obs }}=34,662$ dan $\mathrm{F} \alpha=4,038$. Hal ini menunjukkan bahwa $F_{\text {hitung }}>F_{\text {tabel }}$ sehingga $F_{a}$ adalah $D K=\{F \mid F>4,038\}$. Dengan demikian, dapat disimpulkan bahwa terdapat pengaruh penerapan pendekatan PMRI terhadap kemampuan pemecahan masalah matematis peserta didik.

2) Berdasarkan perhitungan analisis variansi dua jalan sel tak sama bahwa $\mathrm{F}_{\text {obs }}=15,046$ dan $\mathrm{F} \alpha=3,187$. Hal ini menunjukkan bahwa Fhitung $>F_{\text {tabel }}$ sehingga $F_{b}$ adalah $D K=\{F \mid F>3,187\}$. Dengan demikian, dapat disimpulkan bahwa terdapat pengaruh kemampuan multiple intelligences(logis-matematik, verbal-linguistik, dan interpersonal) peserta didik terhadap kemampuan pemecahan masalah matematis.

3) Berdasarkan perhitungan analisis variansi dua jalan sel tak sama bahwa $\mathrm{F}_{\text {obs }}=0,073$ dan $\mathrm{F} \alpha=3,187$. Hal ini menunjukkan bahwa $F_{\text {hitung }}<\quad F_{\text {tabel }}$ sehingga $F_{\alpha b}$ adalah $D K=\{F \mid F<3,187$ \}. Dengan demikian, tidak terdapat interaksi antara pendekatan PMRI dengan kemampuan multiple intelligents terhadap kemampuan pemecahan masalah matematis.

Berdasarkan hasil uji analisis variansi dua jalan sel tak sama yang menunjukkan bahwa terdapat keputusan uji hipotesis nol ditolak. Maka dilakukan tindak uji lanjut yaitu menggunakan metode scheffe'. Analisis data komparasi ganda dengan metode scheffe' dapat dilihat pada Tabel 2 sebagai berikut: 
Tabel 2. Tabel Rataan Marginal

\begin{tabular}{|c|c|c|c|c|}
\hline \multirow{2}{*}{$\begin{array}{l}\text { Pendekatan } \\
\text { Pembelajaran }\end{array}$} & \multicolumn{3}{|c|}{ Multiple Intelligences } & \multirow{2}{*}{$\begin{array}{c}\text { Rataan } \\
\text { Marginal }\end{array}$} \\
\hline & L-M & V-L & I & \\
\hline PMRI & 88,333 & 79,364 & 69,818 & 78,838 \\
\hline Konvensional & 71,800 & 60,333 & 49,769 & 60,634 \\
\hline $\begin{array}{c}\text { Rataan } \\
\text { Marginal }\end{array}$ & 80,067 & 69,848 & 59,294 & - \\
\hline
\end{tabular}

Pada hipotesis pertama, telah diketahui pada perhitungan analisis variansi dua jalan dengan sel tak sama di atas bahwa $H_{0 \mathrm{~A}}$ ditolak, akan tetapi tidak perlu dilakukan uji komparasi ganda antar baris karena kelompok penelitian hanya ada dua saja. Berdasarkan Tabel 2., dapat disimpulkan bahwa penerapan pendekatan PMRI lebih baik dibandingkan pendekatan ekspositori. Hasil ini sekaligus melengkapi penelitianpenelitian sebelumnya terkait penerapan pendekatan PMRI seperti yang dilakukan oleh (Idris \& Silalahi, 2016), serta (Muchlis, 2012) yang memberikan hasil bahwa pendekatan PMRI dapat menghasilkan hasil belajar yang lebih baik dibandingkan pendekatan biasa. Selanjutnya berdasarkan Tabel 1., peneliti akan melakukan uji komparasi ganda antar kolom yaitu pada multiple intelligences (kecerdasan kecerdasan logis-matematik, kecerdasan verballiguistik, dan kecerdasan interpersonal). Uji dilakukan dengan rerata marginal kecerdasan logis-matematik dengan kecerdasan verbal-linguistik ( $\mu_{1}$ vs $\left.\mu_{2}\right)$, rerata marginal kecerdasan logismatematik dengan kecerdasan interpersonal $\left(\mu_{1}\right.$ vs $\left.\mu_{3}\right)$, dan rerata marginal kecerdasan verbal-linguistik dengan kecerdasan interpersonal ( $\mu_{2}$ vs $\left.\mu_{3}\right)$. Berikut disajikan analisis data komparasi ganda antar kolom :

Tabel 3. Uji Komparasi Ganda Antar Kolom

\begin{tabular}{cccrl}
\hline No & Interaksi & $F_{\text {hitung }}$ & $F_{\text {tabel }}$ & Kesimpulan \\
1 & $\mu_{1} v s \mu_{2}$ & 6,342 & 6,373 & $\mathrm{H}_{0}$ diterima \\
2 & $\mu_{1} v s \mu_{3}$ & 27,860 & 6,373 & $\mathrm{H}_{0}$ ditolak \\
3 & $\mu_{2}$ vs $\mu_{3}$ & 10,402 & 6,373 & $\mathrm{H}_{0}$ ditolak \\
\hline
\end{tabular}

Berdasarkan Tabel 3 pada hipotesis nol yang pertama, diperoleh kesimpulan bahwa tidak terdapat perbedaan kemampuan pemecahan masalah matematis antara peserta didik yang memiliki kecerdasan logis-matematik dengan kecerdasan verbal linguistik. Dengan demikian, peserta didik dengan kemampuan kecerdasan logis-matematik memiliki kemampuan pemecahan masalah yang sama dengan peserta didik yang memiliki kemampuan kecerdasan verbal-linguistik. Hal ini disebabkan karena pada saat pembelajaran, peserta didik dengan kemampuan logis dan verbal selalu tampil aktif. Sehingga dampaknya adalah kedua tipe kecerdasan tersebut memiliki kemampuan pemecahan masalah yang sama. Pada hipotesis nol yang kedua, diperoleh hasil bahwa terdapat perbedaan pengaruh peserta didik yang memiliki kecerdasan logis-matematik dengan kecerdasan interpersonal. Berdasarkan Tabel 2., dapat dilihat bahwa rerata marginal kelompok peserta didik dengan kemampuan logis-matematis lebih baik dibandingkan dengan kelompok peserta didik dengan kemampuan interpersonal, hal ini berarti peserta didik dengan kemampuan logis-matematis memiliki kemampuan pemecahan masalah yang lebih baik dibandingkan dengan peserta didik dengan kemampuan interpersonal. Hal ini disebabkan pada saat belajar, peserta didik dengan kecerdasan logismatematik selalu lebih aktif dibandingkan peserta didik dengan kemampuan interpersonal, dimana peserta didik dengan kemampuan interpersonal lebih suka berbicara yang bukan merupakan bahasan materi yang sedang diajarkan. Pada hipotesis nol yang ketiga, diperoleh hasil bahwa terdapat perbedaan pengaruh peserta didik yang memiliki kecerdasan verbal-linguistik dengan peserta didik yang memiliki kecerdasan interpersonal. Berdasarkan Tabel 2., dapat dilihat bahwa rerata marginal 
kelompok peserta didik dengan kecerdasan verbal-linguistik lebih baik dibandingkan dengan kelompok peserta didik dengan kecerdasan interpersonal, hal ini berarti peserta didik dengan kecerdasan verbal-linguistik memiliki kemampuan pemecahan masalah yang lebih baik dibandingkan dengan peserta didik dengan kecerdasan interpersonal. Hal ini disebabkan pada saat belajar, peserta didik dengan kecerdasan verballinguistik selalu lebih aktif dibandingkan peserta didik dengan kemampuan interpersonal, dimana peserta didik dengan kecerdasan selalu tampil didepan kelas jika ada perintah untuk menjawab soal dari guru.

\section{SIMPULAN DAN SARAN}

Berdasarkan analisis data dan pengujian hipotesis yang telah dilakukan oleh peneliti, maka dapat disimpulkan bahwa (1) terdapat pengaruh Pendekatan PMRI terhadap kemampuan pemecahan masalah matematis; (2) Perbedaan pengaruh antara multiple intelligences terhadap kemampuan pemecahan masalah matematis; (3) Tidak terdapat interaksi antara pendekatan PMRI dengan multiple intelligences terhadap kemampuan pemecahan masalah matematis. Interaksi hanya berpengaruh pada pendekatan PMRI dengan pendekatan kovensional terhadap kemampuan pemecahan masalah matematis sedangkan multiple intelligences tidak terdapat interaksi terhadap kemampuan pemecahan masalah matematis.

Pendekatan yang diterapkan di kelas lebih baik bersifat nyata seperti pendekatan PMRI agar peserta didik belajar dengan pengalaman yang telah dilaluinya. Untuk peneliti selanjutnya silahkan gunakan penelitian ini sebagai bahan referensi.

\section{DAFTAR PUSTAKA}

Astuti, D. N. (2014). Penerapan Pendekatan PMRI dan Model Learning Cycle “5E" untuk Meningkatkan Hasil Belajar Matematika Peserta Didik Kelas III SDN Tegalgondo 1 Malang (PhD Thesis). University of Muhammadiyah Malang.

Ayda, E., \& Widjajanti, D. B. (2014). Pengembangan perangkat pembelajaran teorema pythagoras dengan media berbantuan komputer. Jurnal Riset Pendidikan Matematika, 1(2), 216-226.

Gusnidar, G., Netriwati, N., \& Putra, F. G. (2018). Implementasi Strategi Pembelajaran Konflik Kognitif Berbantuan Software Wingeom Dalam Meningkatkan Kemampuan Pemecahan Masalah Matematis. Jurnal Edukasi Matematika Dan Sains, 5(2), 62-69.

Huda, M., \& Arief, A. (2013). Pengaruh Multiple Intelligences Menggunakan Model Pembelajaran Kooperatif Tipe Jigsaw Terhadap Hasil Belajar Siswa Pada Pokok Bahasan Listrik Dinamis Kelas X Di SMAN 1 Porong. Jurnal Inovasi Pendidikan Fisika, 2(3), 3437.

Idris, I., \& Silalahi, D. K. (2016). Penerapan Pendekatan Pendidikan Matematika Realistik Indonesia (PMRI) untuk Meningkatkan Kemampuan Penyelesaian Soal Cerita pada Kelas VII A SMP UTY. EduMatSains, 1(1), 73-82.

Muchlis, E. E. (2012). Pengaruh pendekatan pendidikan matematika realistik indonesia (PMRI) terhadap perkembangan kemampuan pemecahan masalah siswa kelas II SD Kartika 1.10 Padang. EXACTA, 10(2), 136-139.

Putra, F. G. (2017). Eksperimentasi Pendekatan Kontekstual Berbantuan Hands On Activity (HoA) Terhadap Kemampuan Pemecahan Masalah 
Matematik. Al-Jabar: Jurnal Pendidikan Matematika, 8(1), 73-80. https://doi.org/10.24042/ajpm.v8i1 .1148

Sembiring, R. K. (2014). Pendidikan Matematika Realistik Indonesia (PMRI): Perkembangan Dan Tantangannya. Journal on Mathematics Education, 1(1), 11-16. https://doi.org/10.22342/jme.1.1.79 $1.11-16$

Sugiyono. (2011). Metode Penelitian Kuantitatif Kualitatif dan $R \& D$. Bandung: Alfabeta.

Widayanti, F. D. (2010). Pengaruh Pengelompokan Siswa Berdasarkan Gaya Belajar dan Multiple Intelligences pada Model Pembelajaran Learning Cycle terhadap Hasil Belajar Kimia Siswa Kelas XI IPA SMAN 3 Lumajang.(Tesis). DISERTASI Dan TESIS Program Pascasarjana UM. 